ISSN 1112-9867

Available online at

http://www.jfas.info

\title{
STUDY OF TROPHIC RELATIONSHIPS BETWEEN DIASPIDIDAE FAMILY SPECIES -HOST PLANTS -PREDATORS AND PARASITOIDS IN ALGERIA
}

\author{
R. Belguendouz ${ }^{* 1}$, M. Biche ${ }^{2}$ and L. Bendifallah ${ }^{3}$ \\ ${ }^{1}$ Laboratory of aromatic and medicinal plants, Biotechnology department, faculty of nature \\ sciences and life, University of Blida I, Algeria \\ ${ }^{2}$ Agriculture and forestry zoology department, National Superior School of Agricultural \\ sciences (E.N.S.A), Algiers, El-Harrach, Algeria \\ ${ }^{3}$ Laboratory of Soft technology, Valorization, Physical-chemistry of biological materials and \\ Biodiversity, Department of Biology, Faculty of Sciences, University of Mohamed Bougara, \\ Boumerdes, Algeria
}

Received: 07 November 2016 / Accepted: 20 December 2016 / Published online: 01 January 2017

\begin{abstract}
The use of parasitoids and predators in biocontrol contribute to the development of sustainable agriculture, respects environment and human health. In this context, we undertook the identification of natural Diaspididae enemies located on the Algerian territory. Results highlight three predatory families: Coccinellidae, Nitidulidae and Coniopterygidae families, the first represented by the most voracious species as Rhyzobius lophantae living on 19 Diaspines observed on 121 plants, from the northern, and two parasitoid families lived on 39 Diaspididae species affecting 125 plants and were represented by four genera and 23 species such as Aphytis and Encarcia (Aphelinidae) lived on 31 diaspididae species found on 125 host plants. The most voracious and polyphagous species identified are interesting for IPM.
\end{abstract}

Keywords: Diaspididae, Predators, Parasitoids, Host-plant, Algeria

Author Correspondence, e-mail: belguendouz@yahoo.com

doi: http://dx.doi.org/10.4314/jfas.v9i1.9 


\section{INTRODUCTION}

\subsection{Overview of scale insects}

The study of predators and parasitoids of insect pests, mainly of the most harmful species on crops, presents a considerable biological and economical interest. Faced with the real problems engendered by diaspines to agricultural production in Algeria, we found it necessary to devote this work on the study of the insect beneficial of this family insect pest group. Balachowsky has already signalized a number of predators in Algeria such as Cybocephalus seminulum, introduced in Bechar region in Sahara areas to fight against devastating Parlatoria blanchardi a pest of date palm tree, and Cybocephalus flaviseps lives on the same species and other scale species (Paralatoria blanchardi, Diaspis zamiae and Chrysomphalus dictyospermi) [3]. The same author showed, in Algeria and Tunisia, the presence of the Coccinellidae species: Chilochorus bipustulatus on several scales as primary or secondary preys, such as Pharoscymnus setulosus on Aspidiotus hederae and Chionaspis striata and Pharoscymnus anchorgo on P. blanchardi [5]. Although, 16 scale insects predatory ladybirds that infest a small trees has mentioned by Saharaoui $[24,25]$ and several diaspine parasitoids have been described and studied in the world, which some of them were exploited in the biological control, such as Aphytis lepidosaphes against Lepidosaphes beckii [16]. In the Mitidja region (Central part of Algeria), Aphelinus chrysomphali was found specific to Chrysomphalus dictyospermi on orange tree [5] while Aphelinus maculicornis lived depending of Parlatoria pergandii, and A. mytilaspidis on Lepidosaphes conchyformis Lepidosaphes ulmi and Chionaspis berlesei. However, Prospaltella leucaspidis was found specifically live on Leucaspis pusilla and Chiloneurinus microphagus on L. ulmi in northern central part of Algeria [15].

\subsection{Objective and method}

In this study, we contribute to improve our knowledge on the diversity of Algerian beneficial fauna of Diaspididae scale insects and their relationship with host plants. For that, personal investigations were realized in various cultivated crops, forest, ornamental sites and spontaneous vegetation during a study period of three years from 2003 to 2006 in different regions from the North to the South. In addition, we conducted a literature review on an antecedent period works, so that we could establish and actualize the list of the auxiliaryfauna about Diaspididae beneficial enemies.

In sites, we have beginning by to choose the most infested trees and taken branches and leaves and fruits, then we put them in the plastic bags with etiquettes that showed the site, the date 
and the host plant. The samples are brought back to the laboratory of zoology, at the National School of Agronomic Sciences El-Harrah Algiers and kept at $4{ }^{\circ} \mathrm{C}$ in frozen pending treatment and observation of different evolutionary stage of Diaspididae, parasitoids and predators isolated from the plant organs under stereomicroscope ( $\times$ (10 to 100)). The insect's identification method is based on the morphological study of the Diaspididae family according to Balachowsky and Anonymous [7 and 2]. While for predators and parasitoids (Coleopters, Hemipteres), we have referred to the identification key based on a macroscopic morphological examination $[1,23,31]$ and the assistance of the specialists colleagues in zoology per Doctor Lounes Sahraoui and Professor Mohamed Biche at the National school of agronomic sciences (Algiers).

\section{RESULTS AND DISCUSSION}

\subsection{Determination of Algerian Diaspididae group}

Our observations on the Diaspididae and their enemies' richness were made on 93 plant families containing 488 species collected in several sites of Algeria regions from North to South. These plants are the host of 4 subfamilies scales: Aspidiotinae, Diaspidinae, Parlatorinae and Odonaspidinae represented in total by 93 species. We surveyed on these scale insects 17 predator and 21 parasitoids species.

According to the observed plants in both parts north and south, the majority of the collected scales is distributed in the northern part of Algeria. We could distinguish four Diaspididae groups:

1- A ubiquitous (polyphagous) species group that affects several botanical families and lives in several climatic conditions and that are very frequent with high ecological plasticity.

2- An oligophagous species group, which infests one botanical family or one plant genus.

3- A third species group that has preferential host species or genus. They can infest others plants if the preferential host is absent (ex: Parlatoria oleae).

4- A rare species group has food requirements and environment like Parlatoria blanchardi specific to palm date in Biskra, therefore Lepidosaphes ulmi wich prefer the mountains sites and certain species which prefer the forest regions as Leucaspis pini.

\subsection{Relationship between predators-Diaspididae species-host plants}

In the table 1, we illustrate the distribution of predators according to their Diaspididae species-hosts. 
Table 1: Richness of Diaspididae species-predators

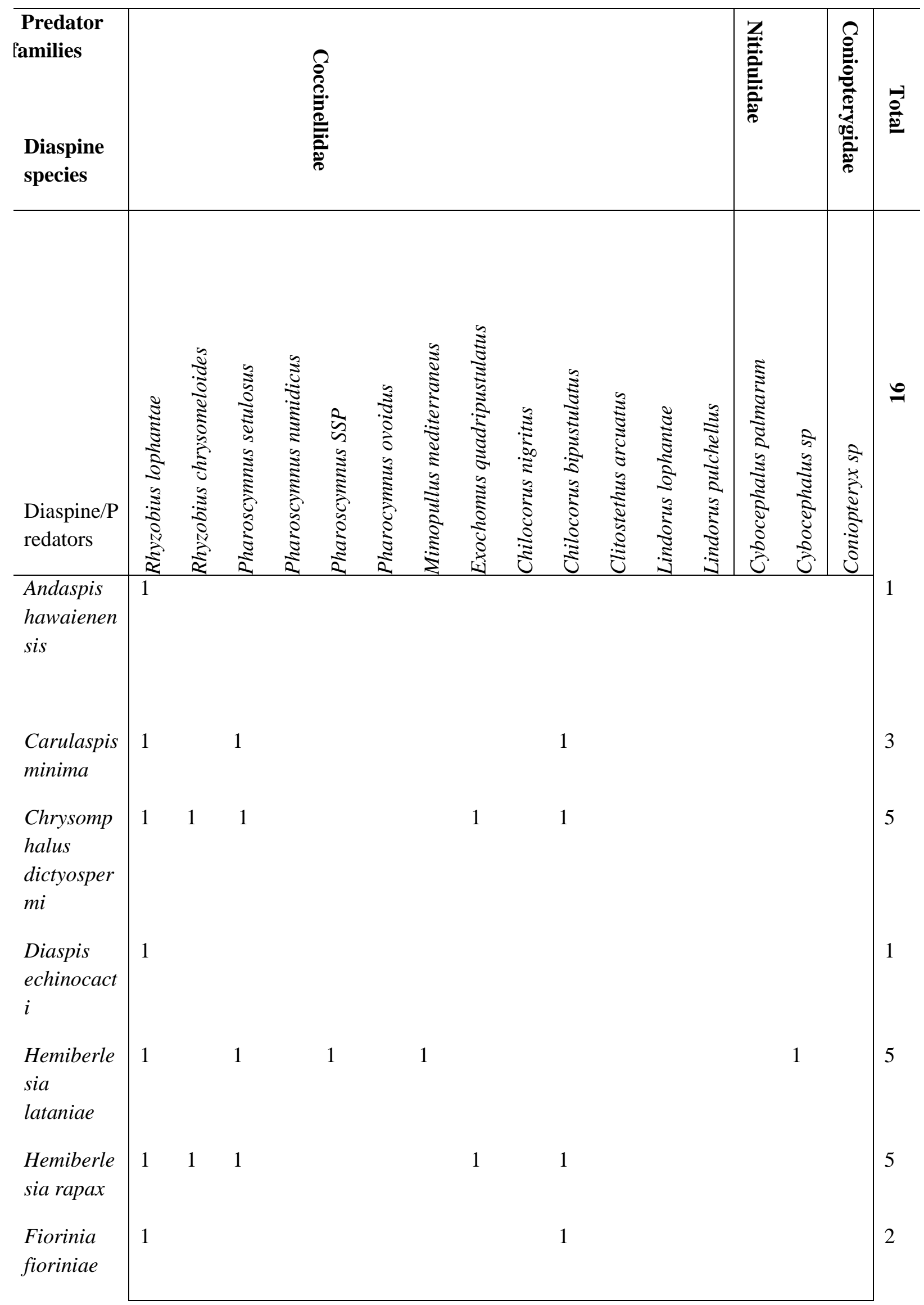




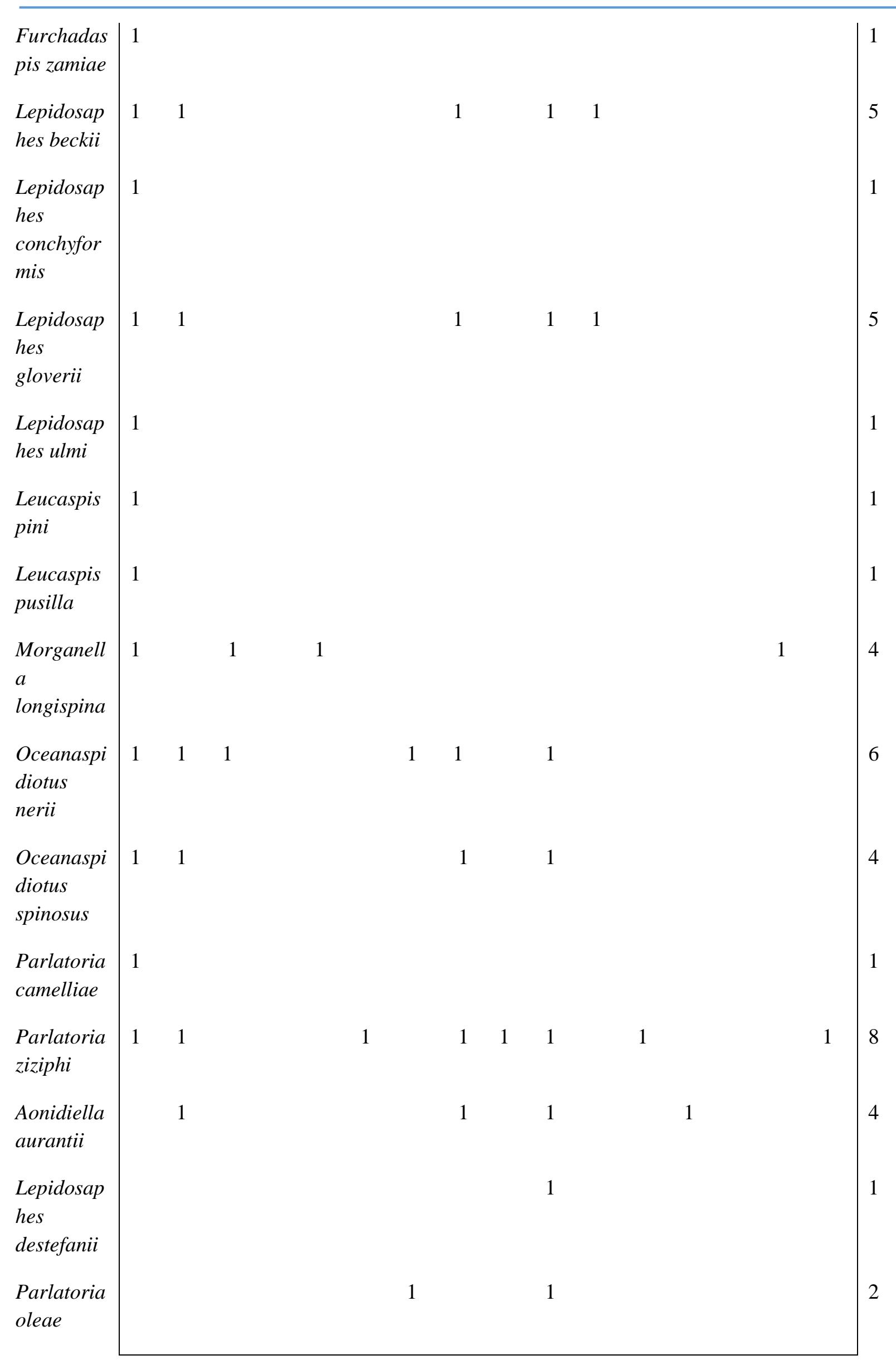




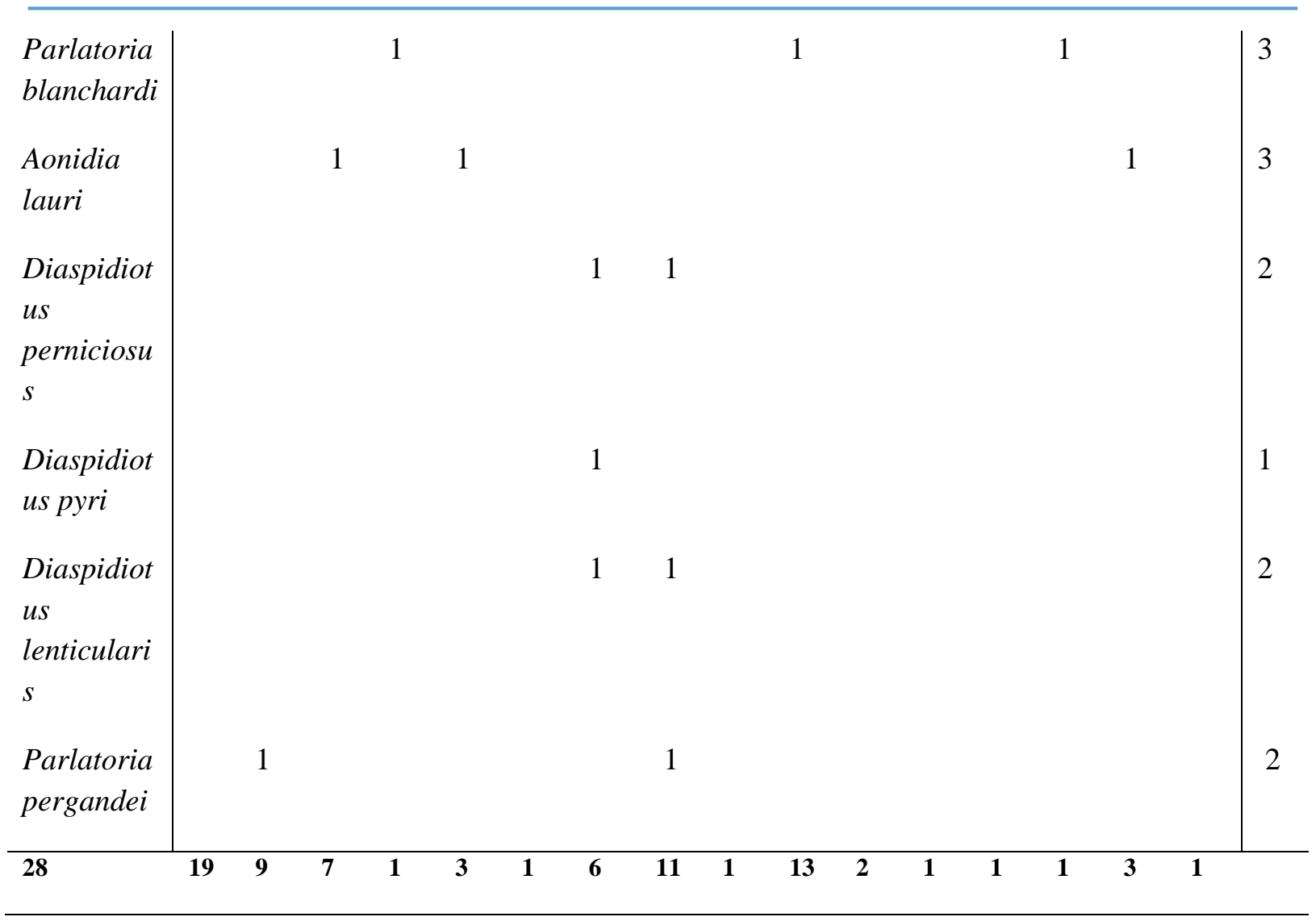

The results in Table 1 reveal the presence of sixteen predator species in Algeria living upon twenty-eight diaspines species those lived on one hundred and fourteen host plants species belonging to thirty-sixe botanical families.

Coccinellidae family contains thirteen species belonging to the genus of Mimopullus, Pharoscymnus, Exochomus, Chilocorus, Clitostethus, Lindorus and Rhyzobius, but Nitidulidae family has only two species belonging to the genus of Cybocephalus and Coniopterygidae one species belonging to Coniopteryx genus.

The most species active on Diaspididae are Rhyzobius lophantae lived on nineteen diaspines living on different plant species (Rutaceae, Cupressaceae, Cactaceae, Cycadaceae, Pinaceae, Oleaceae, etc ...); contrary to Balachowsky [6] who signaled 20 host scale species; followed by Chilocorus bipustulatus lived on thirteen diaspines and manifests a preference for $O$. nerii It is usually found in dry environments, often on shrubs and tree layer (Citrus, Pinus, Picea, Salix, Etc.). The adults overwinter under bark, in leaf litter and under moss and feeds mainly on scale insects. For its part, $R$. chrysomeloïdes is found only on Citrus and feeds mainly scale insects of Lepidosaphes, Aonidiella, Chrysomphalus, Hemiberlesia, Oceanaspidiotus and Parlatoria genus. Pharoscymnus setulosus is found on seven diaspines and Pullus medterraneus on six diaspines. The others lived on one to three diaspines. Chilocorus 
bipustulatus is already noticed as an important predator by [17] and as very specific predator to diaspine scales as Exochomus quadripustulatus which has a wide range of prey. It was observed in association with different populations of scale insects of the genus Aonidiella, Chrysomphalus, Lepidosaphes, Oceanaspidiotus Parlatoria and Diaspidiotus in the tree layer. In the other hand, Cybocephalus palmarum andPharoscymnus numidicus were particularly lived upon Parlatoria blanchardi that infested date palm in the south part of the country, and as it is signaled by [20], Coniopteryx sp. was met only on Parlatoria ziziphi contrary to Kreiter [17] who reported that it was a specific predator of tetranic acariens. The monophagous predator species or those with low predation lived in general on Diaspididae species those affected one or tow vegetable species. According to Balachowsky [6] results, Rhysobius lophantae, Chilocorus bipustulatus are expressing a preference for Aspidiotus nerii but our study confirms that they are polyphagous of thirteen to nineteen scale-hosts. These two species are cited by Blaisdell as predator of A. aurantii as Lindorus lophanthae [12, 22, 27, 8, and 14] and according to Vanachloca study [32], R. lophanthae caused very important (20\%) mortality for A. aurantii by predation in spring. We signaled that Pharoscymnus setulosus has never been met it in south; it coexists and often shares his food with other species such as Chilocorus bipunctatus, Rhyzobius lophantae and Mimopullus mediterraneus. It prefers especially diaspines subservient on Citus, Olea europae, Evonymus japonicus, Pittosporum tobira, Nerium oleander infested by A. nerri, cypress and other forest trees and various cultivated rosacea.

The Nitidullidae family is slightly represented and seldom met on diaspines; it contains two species belonging to Cybocephalus genus. Cybocephalus palmarum is found on palm in Parlatoria blanchardi populations in south while Cybocephalus sp. attend different plant strata in the north (Parlatoria blanchardi, Aonidia lauri, Morganella longispina and Hemiberlesia lataniae). The Lepidoptera are represented by only one family of Coniopterygidae (Nevroptera) which contains only one species Coniopterix sp. regarded as specific host of Parlatoria ziziphi in north central of Algeria [20].

The figure 1 presents the variation of Despines's number and host plant per predator; the polyphagous predators are attracted by polyphageous pest scales which give them more food sources favoring their development and sustainability. This attraction means that the predation is specially oriented to the host, given that the plant has low repellent effect on predators, but it has an effect on predator's guidance in addition to the effect of scale insects species. This relationship is sort of trophic kind established between plants-scale insect and predators that encourage predation. 


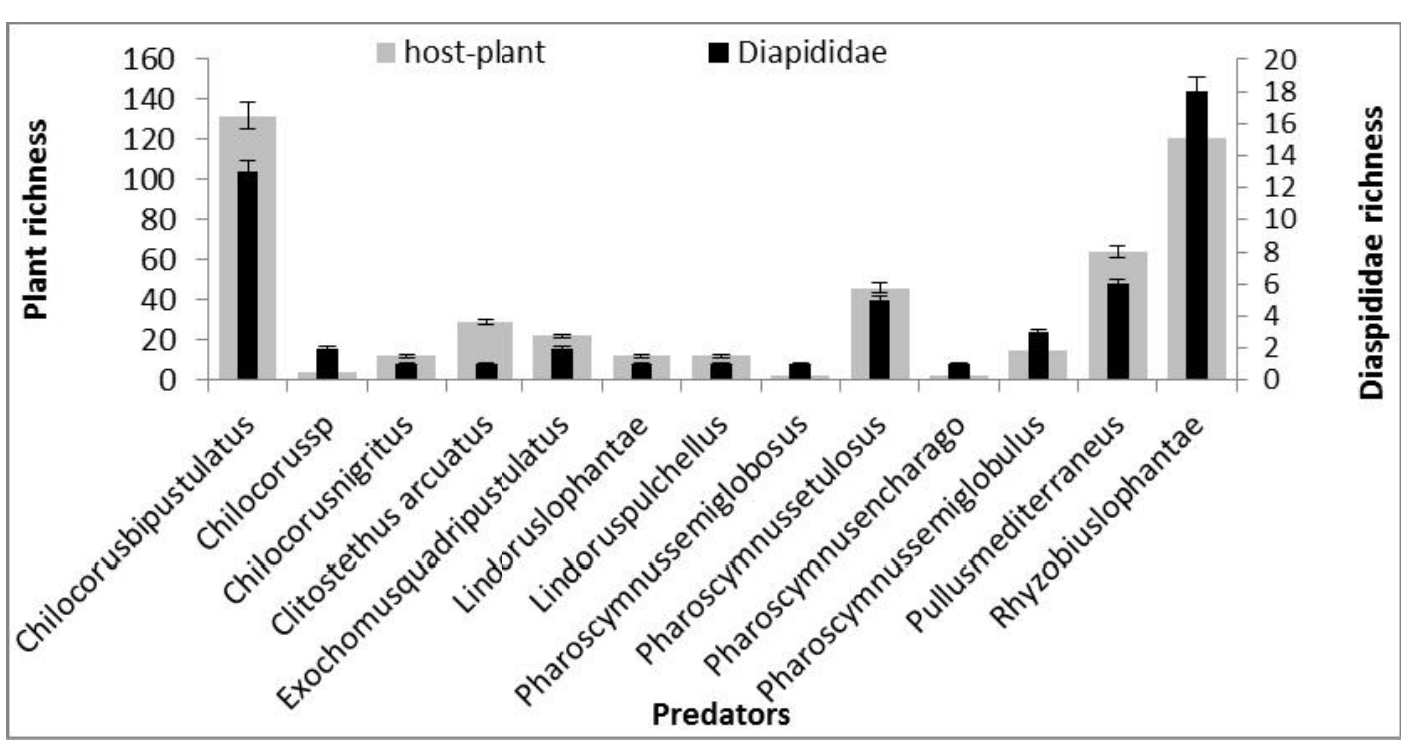

Fig. 1. Richness of host Diaspididae species and host plants species per predator species.

In figure 2, the variation of predator number from one scale species to another is observed. The most coveted by the predators are Oceanaspidiotus nerii, Parlatoria blanchardi, that attract six predators followed by Parlatoria ziziphi, Hemiberlesia lataniae and Lepidosaphes beckii host of five predators and Morganella longispina host of one predator. Lepidosaphes gloverii, Hemiberlesia rapax, Chrysomphalus dictyospermi, Carulaspis minima and Aonidiella aurantii have three predators. The others diaspines have lowest predator number from one to two. This variation is probably related to their specific nutrition or the density of scale insects populations on trees and continuity of their generations, to the nutritional quality which can be demonstrated later by chemical analyses of the nutrients, or to the biotic and abiotic conditions of the medium. We added the effect of the compounds synthetized by secondary metabolism system of the host plant which has an attractive effect on predators. Some predators found on one or two plants don't seem to bear the compounds emitted by plants that certainly have a detrimental effect on their lives. 


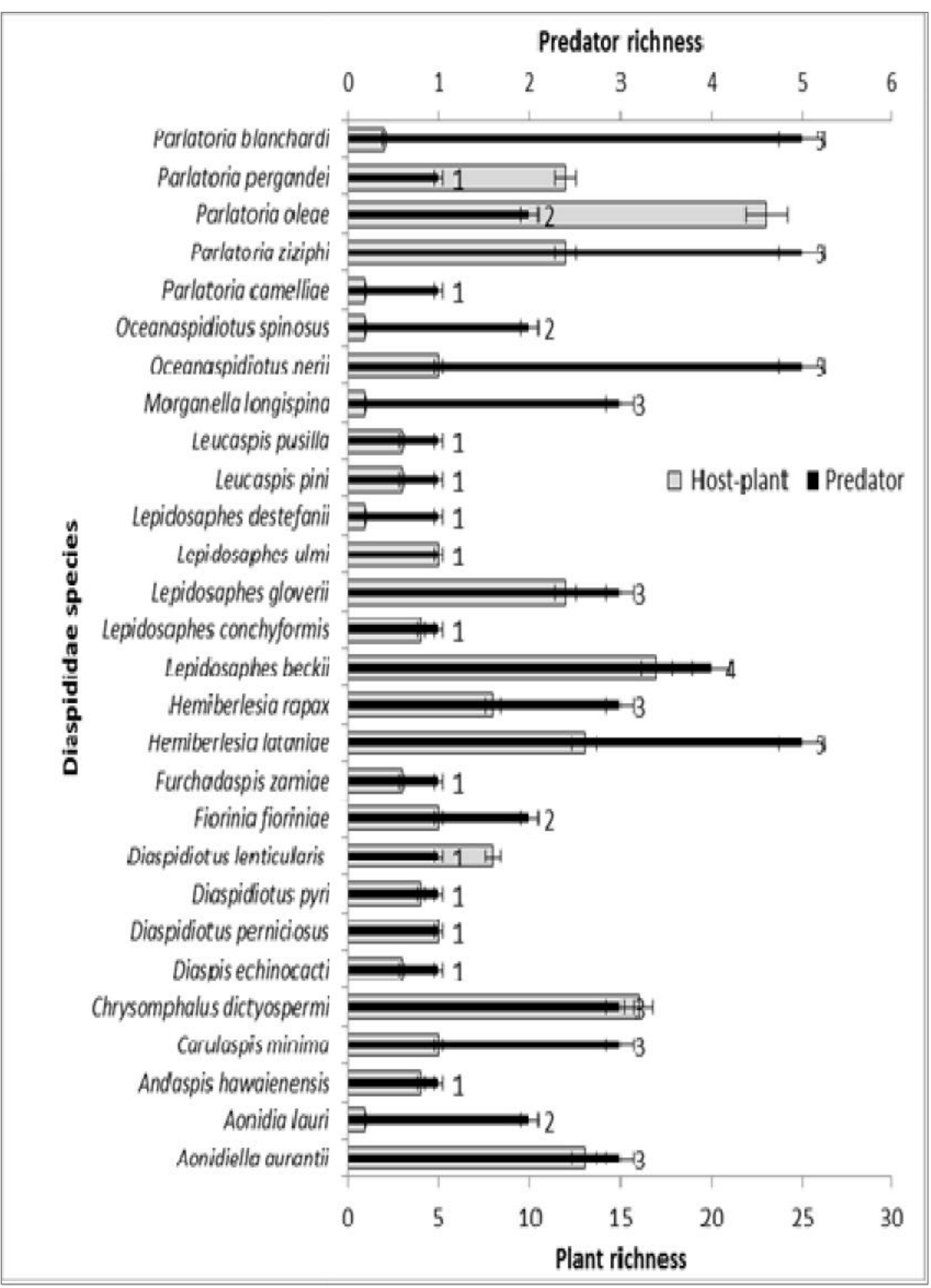

Fig. 2. Richness of predators and host-plants per Diaspididae species.

\subsection{Relationship between parasitoids-Diaspididae species- host-plants}

Variability of predator number from diapines species to another is presented in table 2. 
Table 2: Parasitoids richness of Diaspididae species

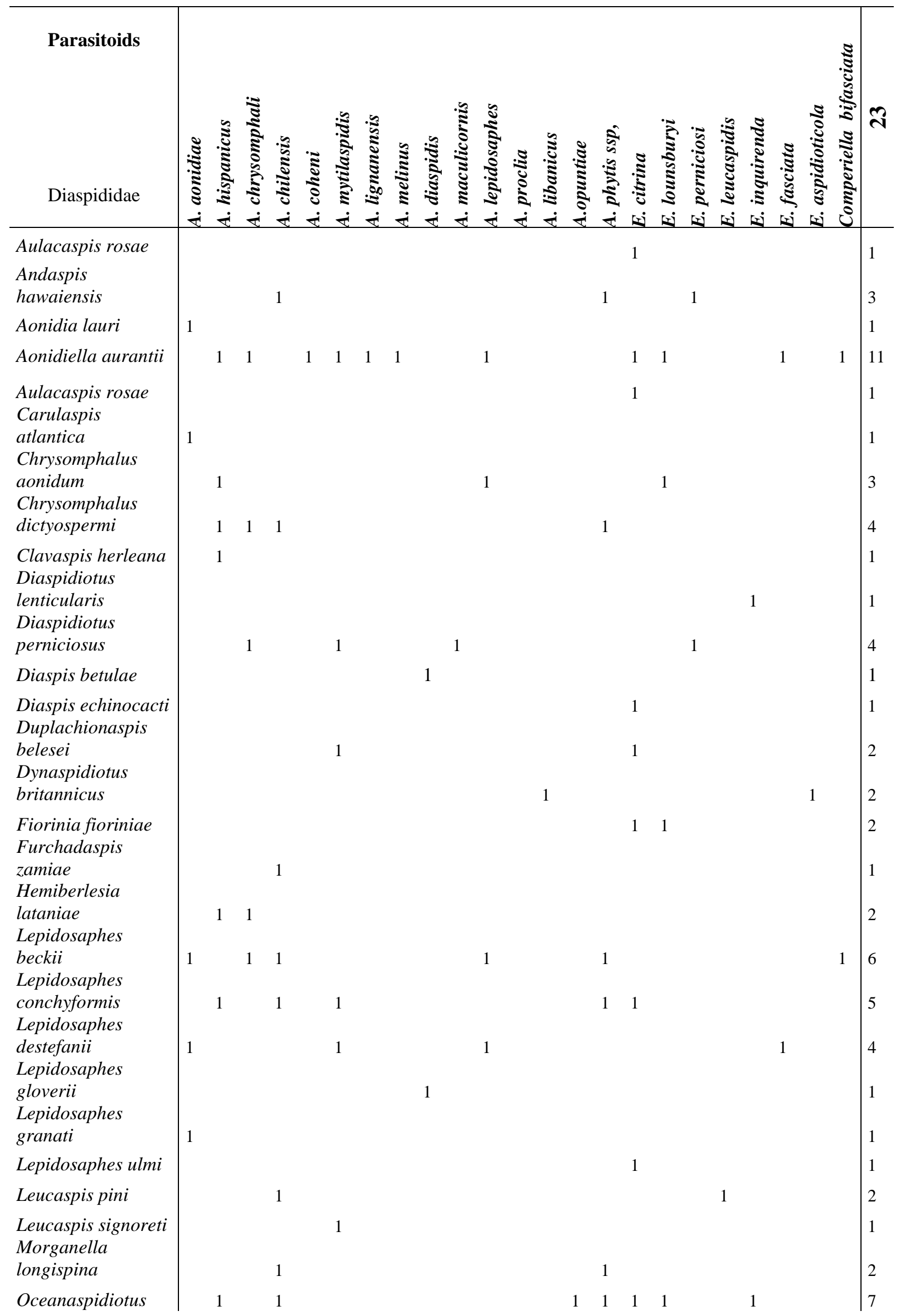




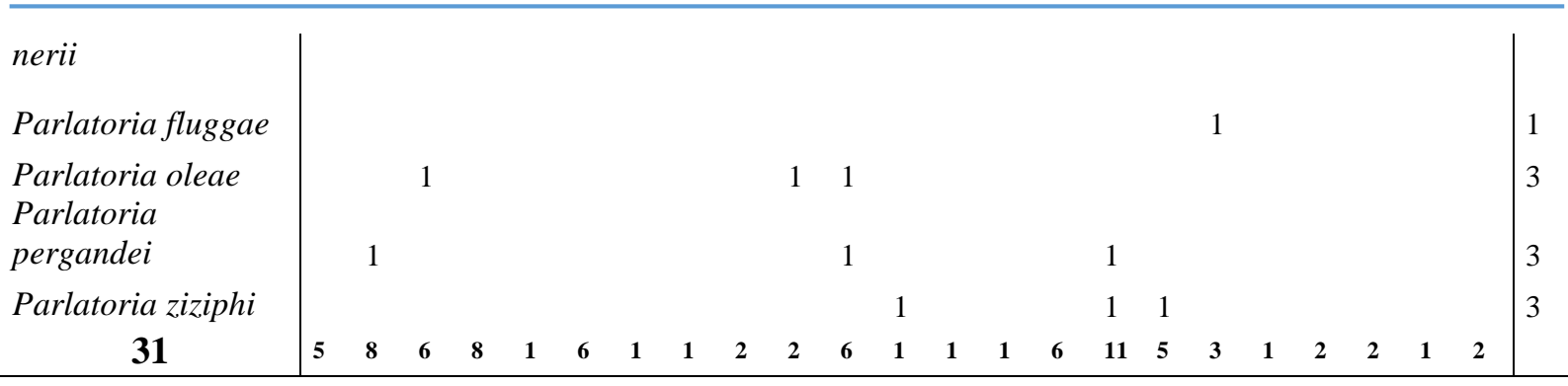

Twenty three parasitoids species belonging to two families of Aphelinidae and Calcidoidae/Encyrtidae were identified. The idiobiont type (Aphytis) and koinobiont type (Comperiella and Encarcia (Aphelinidae) lived on thirty one Diaspididae species witch infested one hundred twenty one plants belonging to forty four plant families.

In the table 2, the most common parasitoid of diaspines is the Aphytis genus, representing fifteen different species, seven of them have high polyphagia, six monophagia and two have lower polyphagia. Aphytis hispanicus and A. chilensis parasitizing sixteen diaspine-hosts living on one hundred seven plants and four plants respectively (Aonidiella, Chrysomphalus, Clavaspis, Hemiberlesia, Lepidosaphes, Oceanaspidiotus, Parlatoria, Andaspis, Firchadaspis, Leucaspis and Morganella), A. chylensis and A. hispanicus parasite eight diaspines living on four plants. A. lepidosaphes, A. mytilaspidis, A. ssp and A. chrysomphali parasite six diaspine-hosts, A. aonidae and E. lounsbeurii parasitize five diaspine-hosts infesting thirty four to fifty plants. The others diaspines have a variable number of parasitoids between one to three host-diaspines infesting three to twenty three plants. On a worldwide Aphytis lepidosaphes is used in the biological fight against L. beckii [16]. In Turkey, several authors affirm that A. melinus can adapt to a new site more easily than A. lignanensis which seems rather promising and well adapted to the citrus orchards [30]. Second polyphageous cosmopolitan species is Encarsia citrina has a worldwide distribution and is the most common parasite of Diaspididae [33]. We observed it on eleven diaspines infesting hundred fourteen plants in Algeria (Fig.3). It has cited by Noyes [19] as parasitoid of Chrysomphalus, Diaspis, Hemiberlesia, Lepidosaphes, Quadraspidiotus and Pseudaulacaspis pentagona and by Balachowsky, Laporte and Poutiers [6, 18, 21] as primary common endophagous parasitoid of Diaspidiotus pernisiosus, Hemierlesia rapax and Pseudaulacaspis pentagona in the mediterranean region. This parasitoid gave satisfactory results following its use against the San Jose scale, Diaspidiotus perniciosus in various European countries [11]. Third parasitoid is Compereilla bifasciata how shows a lower polyphagia and live on two diaspines (A. 
aurantii and L. beckii), those infest twenty night plants (Fig.3). This parasitoid Is an Encyrtidae solitary endoparasitoid, has a little influence upon populations of A. aurantii [10] and introduced to the successful biological control in citrus areas of California, France, South Africa, Israël, Syria, Turkey, Morocco and Italy [13, 9, 26]. The low number of some parasitoids (Aphytis, Compereilla) is bound, probably, with their specification and preference of the host where or with to be able to them of acclimatization in the conditions of the sit. This change in the number of parasitoids seems to have a live relationship with the host plant; because some of them don't can infest several diaspines found on several plants so they are monophageous or undergo the repellent effect of the plant.

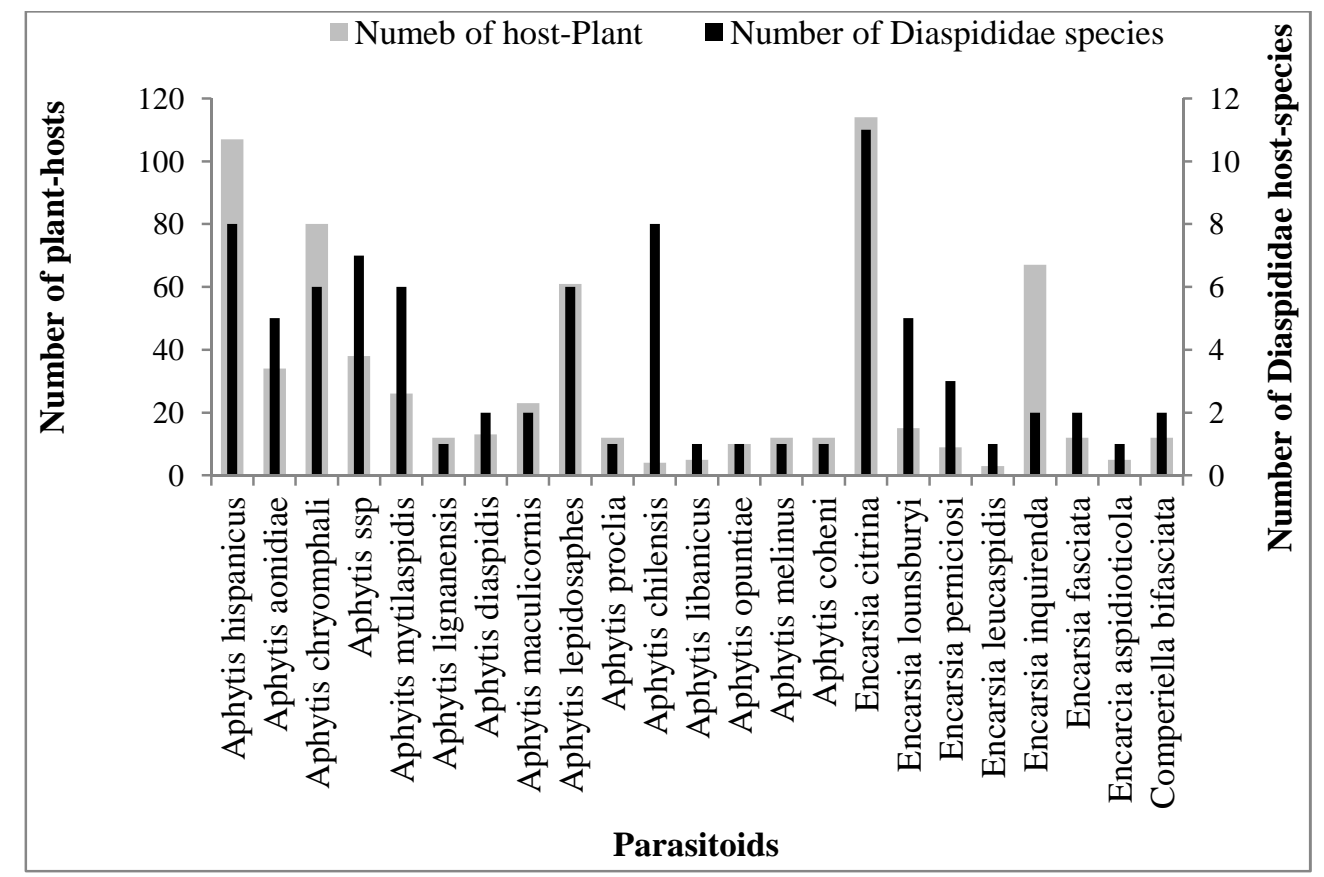

Fig. 3. Richness of parasitoids and host plants per Diaspididae species.

The most parasitized Diaspidiae species are A. aurantii with ten parasitoids; followed by Lepidosaphes beckii and L. conchyformis forma conchyformis with four parasitoids, $L$. destifanii, Parlatoria pergandii, P. olea, Chrysomphalus aonidum, Diaspidiotus perniciosus, Duplachionaspis berlesei, and Dynaspidiotus britanicus with three parasitoids. The other Diaspidiae species are only parasitized by one to two parasitoids. The variation of the parasitoid number from one scale-host to another is probably, related to the choice of the host species, the ecological conditions effects, the acclimatization to the environment and the attractive effect of the plants (Fig. 4). 
We found that $50 \%$ of scale species are not parasitized or attacked by predators. This could be partly explained by the effect of the host plants which could be the subject of further researches.

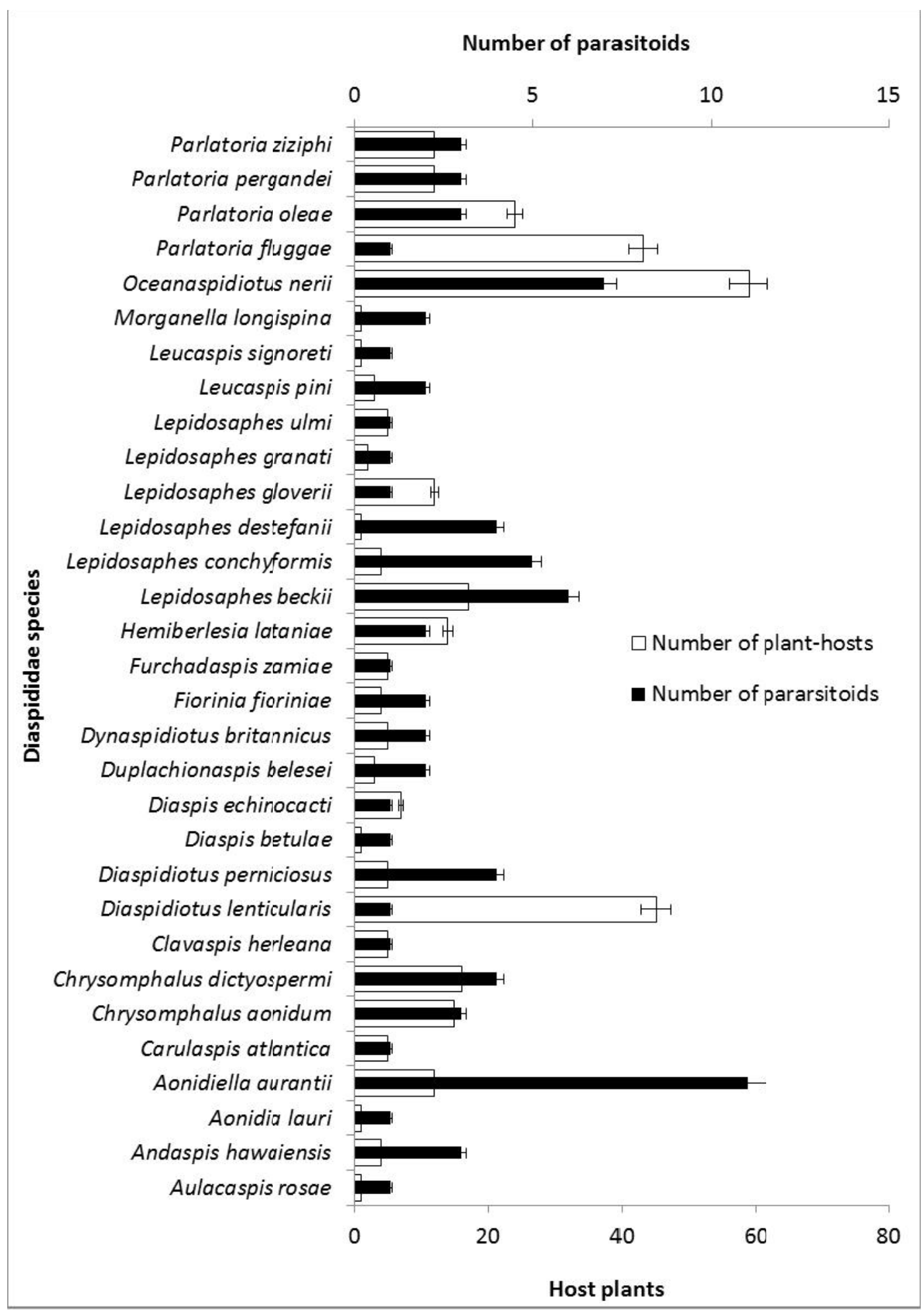

Fig.4. Number of parasitoid and host plant per Diaspididae species 


\section{CONCLUSION}

This first inventory of Diaspididae family predators and parasitoids in Algeria is undertaken for its importance in the biological control of scale insects. It enabled us to bring out the polyphageous species most active of an economic and agricultural interest. Five ladybirds: Rhysobius lophantae, Comperiella bifasciata, Chilocorus bipustulatus, Pullus mediterraneus and Pharoscymnus setulosus activate on sixty-one Diaspididae species and, twenty three parasitoids ectophagous (Aphytis) and endophagous (Compereilla, Chiloneurinus, Aspidiotiphagus), specific or polyphagous activate on till thirty one diaspididae species in Algeria. This group of Diaspididae comprises the most harmful species for Citrus fruits especially date palms, olive and Citrus (P. ziziphi, P. blachardi, P. olea, A. aurantii and L. beckii) which cause major losses to the economy. We note the absence of predators and parasitoids on the same diaspines-host striker different plants species which explains the repellent effect of some of them.

This study can contribute to enrich this inventory for to choice the best predators or parasitoids or both, those are able to adapt to the environment and to control pest populations. For that, it constitutes a starting-point for supplement works in geographical distribution, the determination of virulence and other natural enemies of scale insects, more particularly in difficult accesses sites in southern Algeria regions which still remain to be prospected.

\section{REFERENCES}

[1] Abbasi, 1973. Comperiella bifasciata How. preliminary study (Hymenoptera, Encyrtidae) - endophage Parasite of Californien scale (Aonidiella aurantii Mask.). Al Awamia, Rev., Marocaine agronomic researche. 46. Royaum of Moroco. 32p.

[2] Anonymous, 1978. Generality: Scale insect Diaspididae. I. N. R. A Antibes. Polycop. 27.

[3] Balachowsky, A.S., 1925. Note on two predators of Parlatoria blanchardi Targ. and their used in biological control against this coccid. Bull. Soc. Hist. Nat. Afr. Nord, 16(), 167172.

[4] Balachowsky A., 1926. Note on acclimatization predators of Parlatoria blanchardi in the palm of Colomb- Bechar (Bull. Sci. Hist. Nat. Af. Nd, Alger.

[5] Balachowsky A., 1926 - 1928. Observations biologiques sur les parasites des Coccides du nord de l'Afrique. (Contribution Biological observations on pest coccids northern Africa. (Contribution to the study coccids Minor Africa 5th note (1) 33p. 
[6] Balachowsky A., 1932. Biological Study of western Mediterranean basin coccids. Entomological encyclopedia. Eds. XV. Paris. P. Lechevalier and son. 214PP.

[7] Balachowsky A.S., 1950. Scale insects from France, Europe, North Africa and the Mediterranean Basin. V. -monograph Coccoidea ; Diaspidinae (second part) Aspidiotini. Entomological News Applicata Sciences and Industrial 1087, pp : 397-557.

[8] Bedford, E.C.G., 1998. Red scale Aonidiella auranii (Maskell). In: Bedford, E.C.G., Van den Berg, M.A. and De Villiers, E.A. (eds), Citrus pests in the Republic of South Africa. Dynamic Ad., Nelspruit, South Africa: 132-144.

[9] Benassy, C. and Bianchi, H. 1974. Observations sur Aonidiella aurantii Mask. Et son parasite indigene Comperiella bifasciata How. (Hymenoptera. Encyrtidae). OILB/WPRS Bulletin, 3: 39-50

[10]Brewer R.H., 1971.The influence of the parasite Comperiella bifasciata How. on the populations of two species of armored scale insects, Aonidiella aurantii (Mask.) and A. citrina (Coq.), in South Australia. Australian Journal of Zoology 19(1) · January . DOI: 10.1071/ZO9710053. 11p.

[11] Cahuzac, D. 1986. Les cochenilles des ligneux d'ornement. Phytoma, 383: 37- 38. pp. 132-144.

[12] Crouzel, I.S., H.G. Bimbonim, M. Zanelli, and E.N. Botto. 1973. Lucha biológica contra la cochinilla roja australiana Aonidiella aurantii (Maskell) (Hom. Diaspididae) en cítricos. Revista de Investigaciones Agropecuarias, [13]

[13] DeBach, P., 1948. The establishment of the Chinese race of Comperiella bifasciata on Aonidiella aurantii in southern California. Journal of Economic Entomolgy, 46, 1103. INTA, Buenos Aires, Argentina Serie 5, Patología Vegetal, 10: 251-318.

[14] DeBach, P.D., and D. Rosen. 1976. Armored scale insects. In: Studies in biological control. Delucchi V.L., (Ed.), Cambridge University Press, London, New York, Melbourne, pp. 139-178.

[15] Delassus M.; Balachowsky A.; Brichet J and Lepigre A., 1927. Enemies of fruit culture in Algeria, and practical methods to combat them. (Les ennemis des cultures fruitières en Algérie et les moyens pratiques de les combattre), Alger 197 pp.

[16] Fabres G., 1974. Contribution to the study of Aphitis Cochereaui and Aphitis lepidosaphes (Hym. Aphelinidae) parasitoids of Lepidosaphes beckii (Hom. Diaspididae) in new Caledonia. French entomological society Anal. Fr. (N.S.) I0 (2), 371 à 379. 9P.)

[17] Kreiter S., 2008. SupAgro. Montpellier. Morphology, Biology, interest and limits. 66p. 
[18] Laporte M. L., 1948. New hosts of Apidiotiphagus citrinus How. (Him. Chalcididae) parasite of de cochineals in Algeria. Rev. Path. Vég. Ent. Agr. France, 27. №1.

[19] Noyes J. S., 2001: Interactive catalogue of world Chalcidoidea. Taxapad. Scientific names for information Management (base de données sur support sur cédé-Rome. In Germain J-F., Matile D., Picart J.I., Delvare G., Piron M.: Ferrero Inventaire des cochenilles sous serre en France et connaissance de leur parasitoïdes Un préalable au développement de la lutte biologique. AFPP. $6^{\text {ème }}$ conférence international sur les ravageurs en Agriculture. Montpellier, 4-5-6 Décembre 2002. 8p.

[20] Ouzani T., 1984. Bio-ecological approach of the orange black scale Parlatoria ziziphi Lucas (Homoptera - Diaspididae) in Mitidja. Thesis Ing., Institut. Nat. Agro., El-Harrach, $72 \mathrm{p}$.

[21] Poutiers R., 1928. Observation on few hymenoptera parasites Coccids on Mediterranean littoral. Rev. Path. Veg. Ent. Agr. France, $15 \mathrm{~N}^{\circ} 9$.

[22] Rosen, D. and P. DeBach. 1978. Diaspididae. In: Clausen, C. P. (ed) Introduced Parasites and Predators of Arthropod Pests and Weeds. U.S.D.A. Agric. Handbk. No. 480, Washington, D.C.

[23] Rosen, D. and P. DeBach. 1979. Species of Aphytis of the world (Hymenoptera: Aphelinidae), Dr. W. Junk Publishers, The Hague, Boston, London.

[24] Saharaoui L. 1994. Inventory and study of some bio-ecological aspects of entomophagous ladybugs (Coleoptera, Coccinelidae) in Alegria, J. Afr. Zool. Vol. 108 (6) pp 538-546.

[25] Saharaoui L. 1988. Inventory entomophages beetles (Coleoptera, Coccinelidae) in the Mitidja plain and overview ecological biomajor species of their rol. Algeria. Dipl. Univ., Univ. Research. Nice. 131p.

[26] Siscaro, G., Di Franco, F. Zappalà L., 2008. On the presence and diffusion of Comperiella bifasciata How. (Hymenoptera: Encyrtidae) in Southern Italy. IOBC/wprs Bulletin 38, 42-45.

[27] Smith, D., G.A.C. Beattie, and R. Broadley , 1997. Citrus pests and their natural enemies: integrated pest management in Australia. Queensland Department of Primary Industries, Brisbane, Australia, 272 pp.

[28] Rosen D. and Debach P., 1979. Species of Aphytis of the world (Heminoptera, Aphelinidae). Series Entomologica 17. DR. W. Junk BV Publishers, The Hauge- BostonLondon.108p. 
[29] Thompon, W. R., 1944. Catalogue of insect pest parasites and predators of Sect.1. Pt. 3. Hemiptera. Belleville. Ontario. Canada.

[30] Tuncyirek, 1970. Scale insects harmful to citrus. Plant Protection Institute Bornova-Izmir (Turquie). Al awamia, 37, pp. 67-80.

[31] Traboulsi R., 1968. Contribution to the study of Aphytis Howard of Libanon (Him., Calcidoidae) (1).Ann. Soc. Ent. Fr. (n. s), 5 (I), 1969, 5 - 72. 69p.

[32] Vanaclocha, P., A. Urbaneja, and M.J. Verdú, 2009. Natural mortality red louse of California, Aonidiella aurantii in citrus Valencia and its associated parasitoids. Bol San Veg Pest 35: 59-71.

[33] Viggiani G., 1990. Endoparasitoids. In: D. Rosen (Ed.): Armored scale insects. Their biology, Natural enemies and control. Vol. B. (WorldCrop Pests; 4B). Elsevier. Barking, United Kingdom.

\section{How to cite this article:}

Belguendouz R, Biche M, Bendifallah L. Study of trophic relationships between diaspididae family species -host plants -predators and parasitoids in algeria. J. Fundam. Appl. Sci., 2017, 9(1), 119-135. 